\title{
Typifying Mechanisms for Gender Digital Equity in Latin America
}

\author{
Gabriela Marín-Raventós $^{1(\sqrt{1})}$ and Marta Calderón-Campos ${ }^{2}$ \\ ${ }^{1}$ CITIC-ECCI, Universidad de Costa Rica, San Pedro, Costa Rica \\ gabriela.marin@ucr.ac.cr \\ 2 ECCI, Universidad de Costa Rica, San Pedro, Costa Rica \\ marta.calderon@ucr.ac.cr
}

\begin{abstract}
Gender digital equity in Latin America and the Caribbean is our goal. We analyze gender specific structural inequalities that constitute barriers for women's access to ICT: such as education, traditional cultural beliefs and practices, and economic inequality. We argue also that male-dominated ICT design and implementation (functionality, content, and human-computer interaction) can inhibit gender digital equity. We present a model to typify the existing mechanisms for reaching gender digital equity and propose a new mechanism: creating gender consciousness in ICT design and construction, and attracting women to the ICT field. The proposed model reflects the four mechanisms and depicts the possible means through which they can be implemented. Moreover, the model appoints actors capable of and responsible for such means. Recommendations for the ICT community regarding gender digital equity are also included.
\end{abstract}

Keywords: ICT and gender · Inequity $\cdot$ Digital divide $\cdot$ Digital equity

\section{Introduction}

Latin America and the Caribbean is a middle-income region, with the majority of its 42 countries and territories belonging to that category. It is a heterogeneous region, ranging from low income countries, such as Honduras, Nicaragua, Guatemala, Paraguay, Bolivia, and Dominican Republic to higher income, and regarded as more developed countries, such as Chile, Mexico, Argentina, and Brazil [1]. According to the SocioEconomic Database for Latin America and the Caribbean (SEDLAC), $34.3 \%$ of the Latin American population is middle class, with income between $\$ 10$ a day and $\$ 50$ a day; $25.3 \%$ is still under the poverty line of $\$ 4$ a day [1].

In last decades, many countries in Latin America and the Caribbean have made a big effort to close their gender gaps [2]: poverty has been reduced to lower levels, more girls are in school, child mortality has dropped, and diseases are being fought. However, gender issues remain and reduction in gender gaps does not mean that women's empowerment has been reached [2]. In particular gender digital divide is still prevalent in the Region. 
Digital divide is "an inequality in the power to communicate and to process information digitally" [3]. In most existing published research about digital divide, the word gender refers to sex, that is, to biological women and men, since information about gender identity is not available [3]. In our research, we adopt this position.

In the next section we analyze general gender gaps in Latin America and the Caribbean. In Sect. 3, numbers and aspects of the Region's digital divide are presented. Causes of gender digital divide are presented in Sect. 4, with the objective of trying to identify means for obtaining gender digital equity. Understanding ICTs and their potential for the empowerment of women is necessary in order to overcome the gender digital divide. Section 5 describes some different types of projects that have been implemented throughout the region to overcome gender digital divide. Our main contribution is in Sect. 6 where we present a model to typify the existing three mechanisms for reaching gender digital equity and propose a new mechanism: creating gender consciousness in ICT design and construction, and attracting women to the ICT field. Finally, Sect. 7 includes the conclusions and recommendations for the ICT community, which includes government, academia, non-profit organizations, and industry, as a guide for them to design and implement solutions for each of the four mechanism categories mentioned above, in order to contribute to reach gender digital equality and equity.

\section{General Gender Gaps in the Region}

Figure 1 shows that women are still underrepresented in the best-paid professions and receive significantly lower salaries than men. The average gender earning gap between men and women is $58 \%$ in the region. Engineering, including computer-related professions, is the field in which female representation reaches the lowest percentage $(17 \%)$, and the second highest gender earning gap (76\%).

\begin{tabular}{|c|c|c|c|c|}
\hline $\begin{array}{l}\text { OCCUPATION } \\
\text { (SORTED BY AVERAGE MONTHLY EARNINGS, } \\
\text { HIGHEST TO LOWEST) }\end{array}$ & $\begin{array}{l}\text { SHARE } \\
\text { OF } \\
\text { WOMEN }\end{array}$ & $\begin{array}{l}\text { WOMEN } \\
\text { (AVERAGE MONTHLY } \\
\text { EARNINGS*) }\end{array}$ & $\begin{array}{l}\text { MEN } \\
\text { (AVERAGE MONTHLY } \\
\text { EARNINGS*) }\end{array}$ & $\begin{array}{l}\text { GENDER } \\
\text { EARNINGS } \\
\text { GAP }\end{array}$ \\
\hline DIRECTORS AND CHIEF EXECUTIVES & $28 \%$ & 333 & 626 i & $88 \%$ \\
\hline $\begin{array}{l}\text { ARCHITECTS, ENGINEERS AND RELATED } \\
\text { PROFESSIONALS }\end{array}$ & $18 \%$ & 342 & 553 i̊ & $62 \%$ \\
\hline LEGAL PROFESSIONALS & $37 \%$ & 351 & 431 & $23 \%$ \\
\hline HEALTH PROFESSIONALS (EXCEPT NURSING) & $43 \%$ & 289 & 453 & $57 \%$ \\
\hline COMPUTING PROFESSIONALS & $17 \%$ & 233 & 409 & $76 \%$ \\
\hline SENIOR GOVERNMENT OFFICIALS & $29 \%$ & 289 & 404 iी & $40 \%$ \\
\hline BUSINESS PROFESSIONALS & $46 \%$ & 272 & 427 î & $57 \%$ \\
\hline $\begin{array}{l}\text { PRODUCTION AND OPERATIONS DEPARTMENT } \\
\text { MANAGERS }\end{array}$ & $32 \%$ & 310 & 369 & $19 \%$ \\
\hline OTHER DEPARTMENT MANAGERS & $37 \%$ & 302 & 378 & $25 \%$ \\
\hline $\begin{array}{l}\text { PHYSICISTS, CHEMISTS AND RELATED } \\
\text { PROFESSIONALS }\end{array}$ & $43 \%$ & 229 & 351 & $53 \%$ \\
\hline AVERAGE & $33 \%$ & 302 & 479 & $\mathbf{5 8} \%$ \\
\hline
\end{tabular}

Fig. 1. 10 TOP-Paying Occupations in Latin America, CIRCA 2007. (Source: [4]) 
The World Economic Forum introduced the Global Gender Gap Index (GGGI) in 2006 for capturing the magnitude of gender-based differences [2]. Three concepts are important for understanding the GGGI. The first is that it measures gaps rather that levels of attainment. The second is that it measures outcome variables instead of input variables. This means that variables such as rights, culture or customs, considered inputs, are not reflected in the GGGI. Output variables are related to basic rights, such as education and health. The third concept is that the index ranks countries by gender equity rather than by women's empowerment. The GGGI considers four categories: Economic Participation and Opportunity, Educational Attainment, Health and Survival, and Political Empowerment.

According to the World Economic Forum, Latin America and the Caribbean have closed the gender gap by $70 \%$. Since 2006, this region "has shown the most improvement on the overall GGGI and second-most improvement on both the Economic Participation and Opportunity and Political Empowerment sub-indexes" [2].

However, according to the Inter-American Development Bank [5], even with more education than men, women are still concentrated in lower-paid occupations. When comparing men with women of the same age and educational level, men earn 17 percent more than women. Changing household roles and stereotypes is essential to attaining gender equity in the labor market.

Women's reality is still difficult. Too many women still die in childbirth. Employment, salary and decision making gaps still exist. More needs to be done in order to enhance access to education, job opportunities, and reproductive health services.

\section{Digital Divide in Latin America and the Caribbean}

The digital divide is rooted in the very issues that constrain Latin America's overall economic development: income inequality, lack of infrastructure, and still-nascent technological knowledge base [6]. Note that income inequality is not necessarily related to

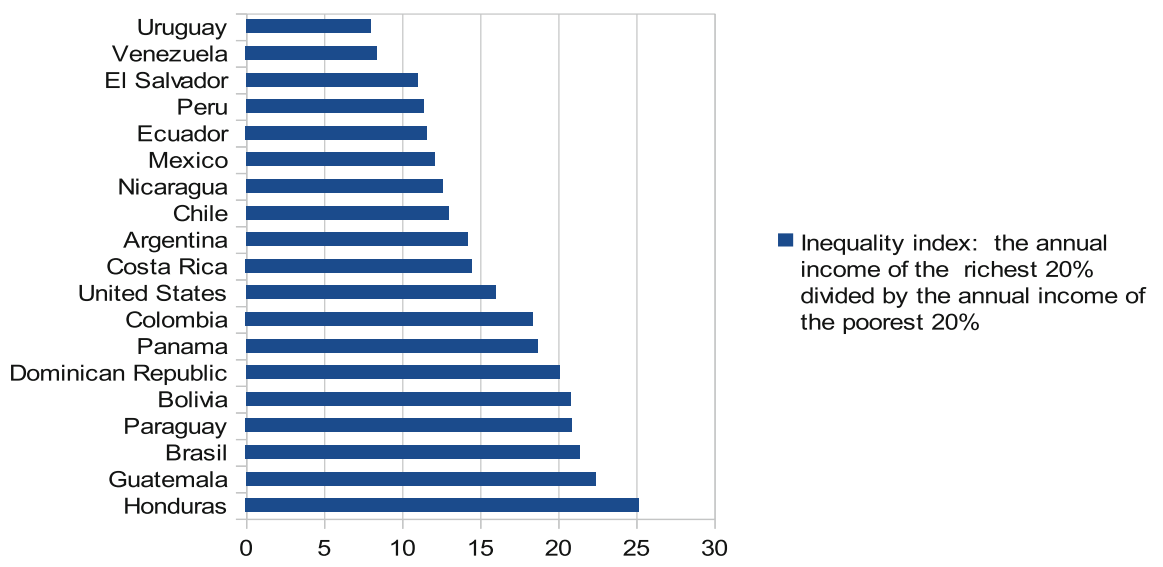

Fig. 2. Inequality in the Americas (Source: [7]) 
a country's wealth. Figure 2 depicts some statistics that highlight the heterogeneity in Latin America's income inequality. Uruguay ranks as the most equitable country in Latin America, with the wealthiest 20 percent receiving 8 times more than the poorest 20 percent. Venezuela comes in at number two. The United States takes eleventh place behind Costa Rica and ahead of Colombia, and several spots below its southern neighbor Mexico. Brasil, Guatemala, and Honduras are regarded as the countries with highest inequality, and therefore, more susceptible to digital divide.

Information and communication technologies (ICT) face constraints in the region, such as a poor legal framework for the development of the ICT sector, heavy administrative burdens, almost non-existing government prioritization for ICT development, low Internet penetration, rates and pervasive brain drain which undermines the potential for faster growth of the economies' ICT sectors [8].

Despite the digital divide has been closing in Latin America and the Caribbean, improvement has been lower amongst women, youth, indigenous peoples, afro-descendants, and rural populations [9].

In order to close this gap, it is necessary to understand the problem of the digital divide. The most difficult barrier to overcome is not related to access (telecommunication infrastructure and dissemination of artifacts), but to use [10]. Opportunities created by technological innovations depend on the use made of them and how they affect the professional development and life of people. The Economic Commission for Latin America and the Caribbean (ECLAC) [11] points out that there is a lag in the ability to adopt and disseminate information technology and systems innovation in Latin America and the Caribbean. They point out that this panorama is even more discouraging given the fact that in recent years, the region's connectivity growth has been the world's fastest. Unequal access of different social sectors to this new technology is their concern. ECLAC warns that the risk of widening the domestic digital divide is greater within the region, than the threat of increasing the gap between the region and the developed world [11].

In particular we are interested in examining how to diminish digital divide existing amongst Latin American and the Caribbean women.

\section{Gender Digital Divide}

Gender digital divide is a reality in many developing countries. Hilbert found that women used Internet less than men, both in Latin America and Africa [3]. Other two differences between men and women, related to having or not a job and attending an educational institution, were found. In both cases, men reach higher employment and educational attainment percentages. However, when eliminating these two facts, that is, when considering only educated and working women and men, women become more active Internet users than men. Technophobic arguments, such as thinking that women have a negative attitude toward ICTs, are no longer valid [3, 12]. However, there are gender specific structural inequalities that constitute barriers for women's access to ICTs. According to [10], they are education, traditional cultural beliefs and practices, as well as economic inequality. 
The gender digital divide can only be overcome reaching gender equality and gender equity. According to the International Fund for Agricultural Development, gender equality "means that women and men have equal opportunities, or life chances, to access and control socially valued goods and resources. This does not mean that the goal is that women and men become the same, but it does mean that we will work towards women's and men's equal life chances [13]." On the other hand, gender equity "means fairness of treatment for women and men, according to their respective needs. This may include equal treatment or treatment that is different but which is considered equivalent in terms of rights, benefits, obligations and opportunities [13]." We believe gender equality is the basis upon which gender equity can be sought.

\section{Towards Gender Equity: Types of Projects}

First, we should be aware that ICTs uses are not gender neutral, even when producers' goal is to sell technology with the least variation in order to lower costs. For example, in a study of How Women and Men Use the Internet [14], Deborah Fallows identified several gender differences: (1) Men are more interested than women en technology and are more tech savvy. (2) Moreover, significantly more men than women: maintain and fix their own computers, are more likely to try new gadgets and applications and software, and are more confident in themselves as searchers and geeks, and pursue and consume information online more aggressively. (3) Women are more enthusiastic online communicators, use email in a more robust way, and are more concerned about general criminal use of the internet than men.

Understanding ICTs and their potential for the empowerment of women is necessary in order to overcome the gender digital divide. Empowering women will give them the capacity to cope with life requirements more efficiently and to transform life conditions. Initiatives for building these two capacities exist and have to be encouraged [10].

In order to build the capacity of coping with life requirements, it is necessary to provide women with the skills that will give them self confidence to use technology. Projects such as TIC-as (ICT-as), under the leadership of the cooperative Sulá Batsú [14], can help to achieve this goal, integrating more women in rural areas to ICTs. Women need to get basic knowledge for using word processors and spreadsheets and navigating in the web. They can also use technology in order to learn about other fields, such as agriculture, legislation, negotiation, marketing, and finance. This can help them to find a job, or a better job, or even, start their own business.

Attracting women to ICT studies is also important because it can help women transform life conditions. ICT is not gender neutral [15]. There are differences between men and women on hardware and software requirements, desired interaction modes, use contexts, and acquisition capacity. Therefore, increasing the participation of women in ICT design and development can help to promote gender digital equity, create awareness of the importance of including gender issues when designing and developing technology, destroy the public perception that ICT is a male domain, ensure a competitive workforce, and enhance the quality of women in general [16]. 
Initiatives such as Meninas Digitais (digital girls) in Brazil [17] and Work Intel Network (WIN) [18] aim primarily at students of high school and technological education, to motivate them to follow careers in ICT. The robotic program of the Fundación Omar Dengo in Costa Rica is designed to develop creativity and innovation skills in children creating and programming robots [19].

It is interesting to note that most initiatives to empower women and to reduce gender digital divide are women driven, and do not correspond to structured public policies.

\section{Typifying Mechanisms for Reaching Gender Digital Equity}

Mechanisms for reaching digital equity must attack several dimensions, since it is not only an economical issue. Several mechanisms have been proposed and implemented. We present a characterization of mechanisms based on the degree of ICT appropriation that women can reach.

The first category is providing women with access to technology. This seems simple, but the effect is not necessarily the expected. Women who have not received training on computers can feel frustrated. If the computer is at home and available for all the members of the family, there is no warranty that women will use it. Women could think that the computer is for her husband and kids, and that it is not worth using it [20]. Access can also be provided through public computer centers, but some women may not visit these places by themselves. If there is a charge for using a computer, women with low income can hardly afford it, and if they can, probably they will find other priorities to invest the money, forexample, to enhance the quality of living of her children. Moreover, moving to a public computer center may not be possible for some women who have to take care of other members of the family. Access to mobile telephones plays an important role, not only because they are low cost devices, but because they are for personal use (not for family use), and can help overcome the impossibility of moving to a public computer center.

The second category is allowing women to learn how to use standard software tools (for example, word processing and spreadsheets). This can be a social activity, so that a group of women can learn together and support amongst themselves. However, these software tools may not be useful enough to make women enthusiastic TIC users. Additionally, as stated before, women may not be able to leave their house and move to the training center, because of distance, cost, or obligation of taking care of someone else.

The third category is empowering women through enabling women to learn how to use ICTs to take control of their lives. TICs can be tools for improving life conditions. Women must be empowered such that they can find out how technology can help them improve their own quality of life: for example, help them control domestic expenses, sell products they produce, increase their income, find employment opportunities, or learn about topics they need to know, such as health, child care and nutrition, among others [3]. Even more importantly, ICTs can help women increase their self esteem. ICTs can become channels to reunite women groups to fight for their own rights. 
Evaluation methodologies are required in order to determine whether an ICT project really improves women's social conditions and promotes a positive change at personal, institutional, community, and social levels. For example, the Gender Evaluation Methodology (GEM), developed by the Association for Progressive Communications (APC), has been used in many initiatives since 2002 [21]. GEM, created with the participation of experts on ICT development in 25 countries from Latin America, Asia, Africa, and Central and East Europe, is useful for determining what role ICTs play in changes that empower women and how this changes shift gender relations between women and men. Methodologies like GEM provide policy makers and the ICT community with feedback that can help them improve the social effects of ICT projects [21].

Moreover, when men and women share the learning experience and work together, in an environment without discrimination in which both have the same participation opportunities, men can change their opinion about women's ability to use computers. This is very important because respect and power relations can become more favorable for women. In Latin America, more than 300 community telecenters have been installed [12]. At these places, people can learn about ICTs and how to use them to promote community development. People, from very different backgrounds, work at these telecenters. The Women's Networking Support Programme (WNSP), of the APC, is "a network of women throughout the world committed to using technology for women's empowerment" [22]. WNSP experiences in telecenters show that the diversity of technological solutions and innovation are promoted when men and women participate in an equitable environment [12].

Previous three categories to pursue gender digital equity have been studied and promoted in most countries. We want to highlight the importance of higher female representation in ICT related jobs as a means to enhance gender digital equity. It constitutes our forth category of mechanisms: creating gender consciousness in ICT design and construction, and attracting women to the ICT field. Women have special gender needs that will hardly be considered if they do not participate in ICT's design and implementation. An interesting example of gender consciousness is that HewlettPackard (HP) discovered that quilters used HP ink-jet printers to transfer patterns onto cloth [23]. This is a female need that HP seriously considered and developed custom quilting software. This decision was taken due to the presence of a significant number of women at HP. Women in the ICT field should become aware of situations such like the shown in this example. Many women in the world are owners of small businesses which could take advantage of ICTs. Paying more attention to their needs could help ICT developers, or women themselves, find new business opportunities which would improve female living and working conditions.

Women on ICT jobs would be the voice of many unheard women and would help achieve gender digital equity. Attracting women to ICT college careers and empowering them to play a proactive role in the professional field is a challenge. Numbers show that the percentage of women studying ICT careers is very low and it is even decreasing not only in our Region [24]. Consciousness on this fact has been obtained but researchers and university department authorities had not succeeded in attracting more women.

Figure 3 evidence the actors, and the means they normally use, to implement the four mechanisms identified to enhance gender digital equity. Most proposals to diminish 
gender digital divide concentrate on the first three mechanisms. However, we believe the fourth mechanism, creating gender consciousness in ICT design and construction, can facilitate the previous three, not only in Latin America and the Caribbean, but globally. Women can design and develop ICT technologies better suited for female needs, can develop more female friendly applications and e-learning tools to promote ICT use amongst the female community, and can help empower women.

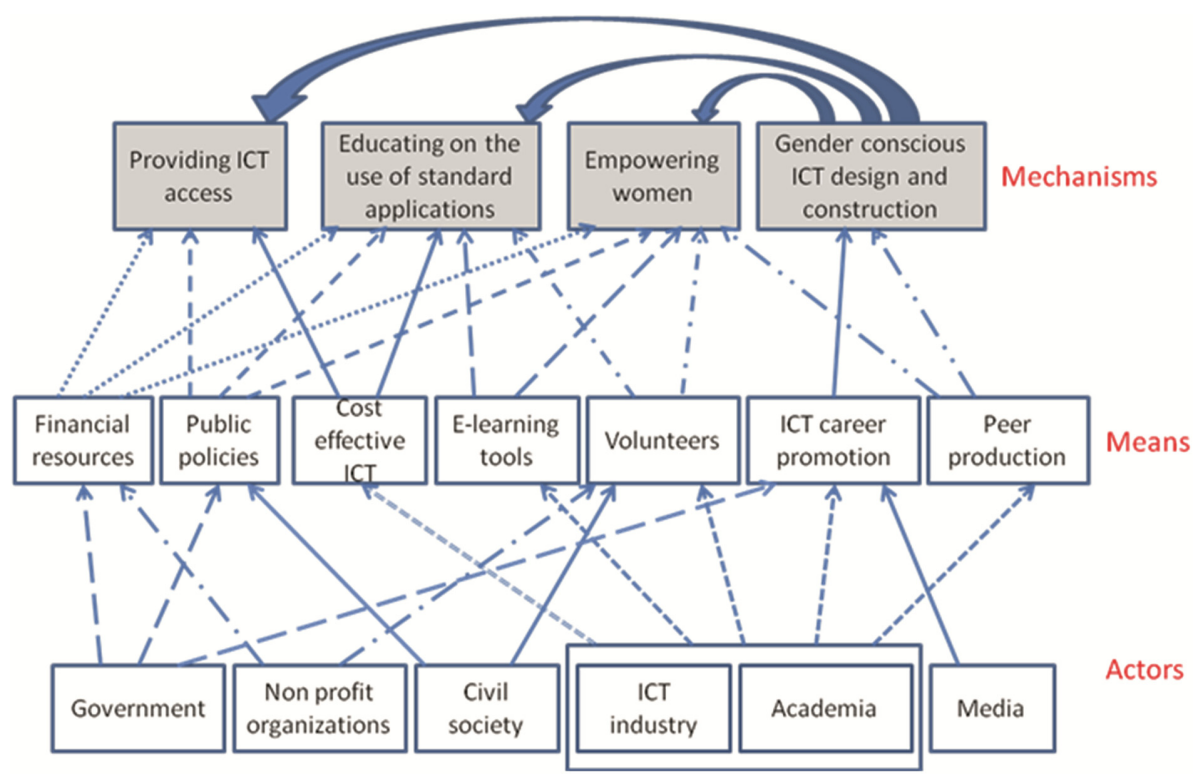

Fig. 3. Mechanisms for Reaching Gender Digital Equity

\section{Recommendations and Conclusions}

The ICT community, which includes government, academia, non-profit organizations, and industry, can contribute to design and implement solutions for each of the four mechanism categories mentioned above, in order to contribute to reach gender digital equality and equity.

For the first category, the ICT community should continue developing cost efficient devices, protocols and communication technologies, in order to warranty low cost access to women. Community access centers are a source to provide access, if schedules are designed to incorporate women's needs, and daycare facilities for children and elderly are provided. Moreover, they must foster an environment in which women can interact with someone who can solve her doubts. Mobile technology may play an important role since they avoid the need to attend community centers. They are easy to use and low cost.

Government policies can provide incentives and financial sources to supply mobile technology access to women. They can impose conditions on companies that want to 
operate in a country, such as obliging an operator to donate telephone connections to the lowest income population.

For the second category, it is important to be aware of the limitations women can face. Developing on-line training programs may be very convenient, because women would not have to leave home, and could choose when to connect and interact with the applications. E-learning is a challenging option requiring the participation of professionals from different backgrounds. Content creation is a major issue, because training applications should be easy to use and should offer options to solve doubts. Usability is a very important feature, since women value it more than men, and may not have too much time to experiment with the application [15].

For the third category, the ICT community should understand women's needs. These are not necessarily standard, since needs could depend on the natural and social environment. An important issue is promoting innovation and entrepreneurship among women. Introducing women to electronic commerce and social networks to sell their products is an example of how this could be achieved.

Another possibility is thinking about how to introduce women in the service sector, that, in general, offers better income conditions that the manufacturing sector. Telework may become helpful to overcome limitations women face when looking for a job. Women could receive necessary job training through on-line applications.

Creating online content that can help women improve their living conditions must be a cooperative activity result of the interaction of the ICT community and women. Examples of key areas of content are education, health, nutrition, and child and elder care. Language used has to be understandable and adapted to the natural and social environment.

Women should not be only content consumers. Introducing women to peer production in any of its two modalities, commons-based and corporate-based, could help them to introduce them in the creation of information (e.g., financial services, accounting) and culture (e.g., music) [25]. This would allow women to get an income and would help balance gender-power relations.

Giving women the possibility of participating in community decisions related to ICT projects makes sense when they have understood the opportunities technology offers. Government policies can enforce female participation in decision making, but cultural aspects could neutralize the possible effects of these policies. Teaching women how they can assume an active role in the Internet governance, through commons-based peer production, would help them to become more autonomous, because they could create services and information by and for themselves and could freely organize in non-hierarchical organizations [25].

The ICT community should also take advantage of international volunteer programs, in which experts in ICT volunteer as tutors in education programs. It would help to lower program costs. For example, from 2001 to 2013, Korea Internet Volunteers (KIT) has contributed with more than 900 volunteer teams, mostly formed by college professors and students, who have supported ICT education programs in 70 countries in Latin America, Africa and other continents [26]. Governments and non-profit organizations should promote local volunteer programs, in which active and retired ICT experts could participate. ICT enterprises could establish social programs in which both the company 
and the employees contribute according to their capabilities. Companies could provide materials and ICT tools helpful to women, and employees could volunteer to work as instructors.

However, the ICT community should understand that introducing ICT in a community is not sufficient to achieve positive social changes. Reviewing existing evaluating methodologies and promoting its use is a pending task.

For the fourth category, creating gender consciousness in ICT design and construction, especially attracting women to the ICT field, is a pending task worldwide. Moreover, retaining them not only while they study, but also during their professional life, requires also our attention. Their presence in classrooms and working places can contribute to get higher levels of innovation and competitiveness.

Women conceptualize a profession mostly based on the opinion of others and the messages they receive from the society [24, 27]. On the other hand, men make their career decision based on their personal experiences with technology, starting from toys they have played with. Therefore, attracting young women to computer-based careers requires of several changes. Young girls should have the same opportunity as boys of playing with toys that let them solve problems and design solutions. Girls should receive support from their parents and professors when they decide to study a technological college career. The ICT community can develop promoting programs showing what ICT professionals do, highlighting the opportunities that ICT offer to improve people's lives and promoting professional development. Media can highlight the achievements of women in technological fields, which would help to change stereotypes that keep young girls away from ICT careers and would provide them with models to follow.

Universities can play a more proactive role in recruiting ICT students. Both female and male professors can visit primary and high schools to talk about possible professional development paths and to resolve the doubts students could have. Some changes on Computer Science curricula can also be beneficial. Changing the program of the career introductory course from a technological approach to an ICT potential impact approach can help women to be sure they made the right decision when choosing career. A mentoring system during the first college year, in which women are empowered and motivated to express their needs and opinions and their self esteem is increased, could help retain them in the ICT field. Promoting a non-discrimination study environment and working on teams in which at least a woman is always present might help male classmates understand that they get better technological solutions when both sexes cooperate.

The ICT community must become aware of the importance of designing technology considering gender differences. The field of gender human-computer interaction has contributed to understand that women and men use computers for different purposes and goals [15], due to differences in their personal interests and in the roles both sexes play within their families and communities. Physical differences (e.g., in weight, height, and strength) should also be considered, in order to avoid personal damage and fatigue. However, there are no general rules that can be applied when identifying special needs of men and women, because human beings are complex and their motivations and interests sometimes can seem contrary to what is expected. If the aforementioned mechanisms for empowering women and helping them empower themselves are effective, 
more Latin American women could become business owners, new needs may emerge, and ICT women may think about them more seriously than men would. It is difficult to do research to prove the possible positive impacts of (1) gender conscious technology design, and (2) greater presence of women in the ICT field, on gender digital equity. Cause effect factors on long term societal phenomena are very hard to measure. We invite the international community to try to propose mechanisms to address this issue, and help us demonstrate the impact of our proposed mechanism.

Finally, to foster gender digital equity, women in ICT related jobs should not limit their activities to designing and building technology. They should also have the opportunity of participating in the definition of related policies, making sure that regulations and incentives necessary to motivate and facilitate the creation and use of applications favoring women, are created and implemented.

\section{References}

1. Socio-Economic Database for Latin America and the Caribbean. Stats. http://sedlac. econo.unlp.edu.ar/eng/statistics.php

2. The Global Gender Gap Report. World Economic Forum, Switzerland (2015)

3. Hilbert, M.: Digital gender divide or technologically empowered women in developing countries? A typical case of lies, damned lies, and statistics. Women's Stud. Int. Forum 34(6), 479-489 (2011)

4. Ñopo, H.: The paradox of girl's educational attainment. In: America's Quarterly, Issue Gender Equality: Political Backrooms, Corporate Boardrooms and Classrooms, pp. 101-104 (2012)

5. Ñopo, H.: New Century, Old Disparities: Gender and Ethnic Gaps in Latin America and the Caribbean. Inter-American Development Bank, Washington, D.C. (2012)

6. Marín, G.: Digital equity and gender issues in Latin America. In: 23rd IFIP World Computer Congress (WCC 2015). http://www.wcc-2015.org/WORKSHOP_ON_DIGITAL_ EQUITY_speakers.php

7. The Huffington Post: U.S. Income Inequality Worse than Many Latin American Countries. http://www.huffingtonpost.com/2013/01/27/us-income-inequality-wors_n_2561123.html

8. World Economic Forum: Singapore overtakes the United States in the World Economic Forum's Global Information Technology Report. http://web.worldbank.org/archive/ website00818/WEB/OTHER/SINGAP-2.HTM

9. Inter-American Development Bank. Gender Equality in LAC and the IDB. http:// www.iadb.org/en/topics/gender-indigenous-peoples-and-african-descendants/genderequality/gender,1926.html

10. Huyer, S, Sikoska, T.: Overcoming the Gender Digital Divide: Understanding ICTs and their Potential for Empowerment of Women. Instraw Researh Paper Series No. 1, April 2003

11. Economic Commission for Latin America and the Caribbean: Digital Divide could Widen in Latin America, http://www.cepal.org/en/pressreleases/digital-divide-could-widen-latinamerica

12. Sabanes, D.: Mujeres y nuevas tecnologías de la información y la comunicación. In: Cuadernos Internacionales de Tecnología para el Desarrollo Humano 2, Spain (2004)

13. International Fund for Agricultural Development. http://www.ifad.org/gender/glossary.htm

14. Fallows, D.: How Women and Men Use the Internet. Pew Research Center Washington (2006). http://www.pewinternet.org/2005/12/28/how-women-and-men-use-the-internet/ 
15. Sula Batsú: TIC-as La ciencia nos necesita. http://sulabatsu.com/ticas/que-es-tic-as/

16. Calderón, M., Marín, G.: Tablet use patterns and drivers of user satisfaction: a gender approach. In: Collazos, C., Liborio, A., Rusu, C. (eds.) CLIHC 2013. LNCS, vol. 8278, pp. 71-78. Springer, Heidelberg (2013)

17. Ashcraft, C., Eger, E., Friend, M.: Girls in IT: The Facts. National Center for Women and Information Technology (2012)

18. Program Meninas Digitais. https://sbcmt.wordpress.com/meninasdigitais/

19. Kass, K.: How Intel Empowers their Female Work Force, United States, Intel. https:// www.simply-communicate.com/case-studies/company-profile/how-intel-empowers-theirfemale-work-force

20. Fundación Omar Dengo: Programa de robótica educativa infantil. http://www.fod.ac.cr/ robotica/index.php/red-de-robotica-educativa/10-proyectos/14-cursos-infantiles

21. Gorano, C., Goñi, M.: TIC para el Cambio Social: Las Mujeres Protagonistas. Intendencia Municipal de Montevideo, Montevideo (2007)

22. Association for Progressive Communications: GEM Gender Evaluation Methodology for Internet and ICTS. http://www.genderevaluation.net/

23. Association for Progressive Communications: Glossary. https://www.apc.org/en/glossary/ term $/ 253$

24. Speizer, I.: By Adding More Women to its Workforce, HP Sees Customer Need More Clearly, Workforce (2004). http://www.workforce.com/articles/by-adding-more-womento-its-workforce-hp-sees-customer-needs-more-clearly

25. Calderón, M.E., Marín, G.: En quién o en qué confían las mujeres para pomar la decisión de estudiar computación. Rev. Novatica 231, 13-21 (2015)

26. Benkler, Y.: La Riqueza de las Redes. Icaria Editorial, Barcelona (2015)

27. Red de Redes Telecentros LAC, Proyectos. http://www.telecentros.org/proyectos.php?id=2

28. Adya, M., Kaiser, K.M.: Factors influencing girls' choice of information technology careers. In: Trauth, E.M. (ed.) Encyclopedia of Gender and Information Technology, pp. 282-288. IGI Global, Hershey (2006) 